MELUZYNA

ISSN 2449-7339

1 (10) (2019) | Rocznik VI

DOI: 10.18318/me.2019.1-01

PRZEKROJE I ZBLIŻENIA

\author{
Robert Mileszczyk ${ }^{\star}$ \\ Uniwersytet Marii Curie-Skłodowskiej w Lublinie \\ ORCID ID 0000-0001-7644-1732
}

\title{
Strategie kreowania wizerunku humanisty w Księdze elegii podróżnych Jana Rybińskiego
}

Jana Rybińskiego sytuuje się zwykle jako drugorzędnego poetę polskiego renesansu, jednak cieszył się on dużym uznaniem wśród sobie współczesnych⒈ Jego twórczość doceniali zarówno pomniejsi poeci, jak i wpływowi magnaci (np. Wacław Ostroróg, Lew Sapieha, Jan Zamoyski, Krzysztof Radziwiłł), na których pomoc i przychylność liczył, szukając w kraju zarobku. Jest też jednym z nielicznych poetów, którym nadano tytuł „poeta regius laureatus”. Przez kilka lat pełnił również funkcję sekretarza królewskiego na dworze Zygmunta III. Początki jego kariery wiążą się bezpośrednio z odbytą za granicą edukacją, głównie w niemieckich uniwersytetach, gdzie zdobył solidne humanistyczne wykształcenie i poznał się z wieloma słynnymi intelektualistami epoki.

Po powrocie do kraju i zakończeniu długiego etapu podróży akademickich, Jan Rybiński pozostał jeszcze do roku 1589 w służbie swoich dawnych mecenasów - Ostrorogów. Udał się następnie do prężnie rozwijającego się - zarówno gospodarczo, jak i kulturalnie - Gdańska, gdzie otrzymał posadę lektora języka polskiego tamtejszego gimnazjum. Kulturę i ikonosferę miasta nad Motławą charakteryzowała wówczas silna tendencja do antykizacji. Nawet na kamienicach można było zobaczyć rzeźby lub płaskorzeźby mitycznych bóstw, herosów czy postaci z historii Rzymu, panowała też powszechna moda na wplatanie sentencji łacińskich w wystrój frontonów budowli czy ich komnat². Gdańsk emanował

\footnotetext{
* e-mail autora: robert.mileszczyk98@gmail.com

1 Na temat biografii Rybińskiego zob. Buszewicz, Ryczek, 2015; Nadolski, 1961; Nadolski, 1976; Nowak, Świderska, 1961; Nowak, 1997.

2 O roli tradycji antycznej w sztuce gdańskiej zob. Grzybkowska, 2000, s. 39-49.
} 
rzymską tradycją, zaś ważną rolę w kształtowaniu tego typu kulturowego naśladownictwa odgrywało, powstałe w 1558 roku, Gimnazjum Akademickie (Bielak, 2000, s. 93-101; Kotarski, 1993, s. 287-302). W tej atmosferze Rybiński spędził ponad trzy lata (1589-1592), jednak pogarszające się od czasu małżeństwa z Anną Glicznerówną warunki materialne gdańskiego lektora zmusiły go do poszukiwania posady zapewniającej mu lepsze wynagrodzenie. To z kolei zaprowadziło poetę do innego, prężnie rozwijającego się miasta, jakim był w XVI wieku Toruń, gdzie podobnie jak kilka lat wcześniej w Gdańsku, potrzebowano wykładowcy języka polskiego do gimnazjum zreformowanego w duchu idei pedagogicznych Jana Sturma. Pod zarządem Henryka Strobanda miasto przeżywało okres prosperity. Szczególnie szkolnictwo, za rektoratu Kaspra Friesego, stało na wysokim poziomie, co w połączeniu $\mathrm{z}$ aktywnym środowiskiem literackim i naukowym czyniło z Torunia wyjątkowo atrakcyjne miejsce dla ambitnego pedagoga i poety (Nowak, Świderska, 1961, s. 342-343; Salmonowicz, 2005).

Niewątpliwie Rybiński dostrzegał możliwości, jakie otwierało przed nim nowe miejsce pracy i chciał zrobić dobre wrażenie zarówno na Radzie Miejskiej, od której zależał jego byt materialny, jak i na miejskim środowisku intelektualnym, w którego szeregi chciał wstąpić. Jego wizytówką był zbiór Hodoeporicorum liber. W nim właśnie ze względu na ten podwójny cel ujawnia się wizerunek Rybińskiego, oscylujący między nastawieniem pragmatycznym a artystycznym. Z jednej strony humanista eksponuje swoją erudycję, znajomość łaciny i greki, oczytanie w starożytnych autorach, wiedzę o antycznej historii, ale też wysoki poziom wykształcenia, obycie w świecie nauki, dyplomacji i administracji, koneksje $z$ wybitnymi personami epoki oraz własne doświadczenie pedagogiczne. Z drugiej strony natomiast ukazuje wizerunek subtelnego i doświadczonego poety, człowieka w pełni oddanego Muzom, wprawnego w posługiwaniu się różnymi gatunkami poetyckimi, artysty należącego do europejskiej wspólnoty intelektualnej. Obie te warstwy harmonijnie łączą się w pełny obraz szesnastowiecznego humanisty.

Swoją erudycję Rybiński ujawnia już we wstępie do cyklu Hodoeporicorum liber, pozdrawiając Radę miasta zręcznie użytym zwrotem greckim, eksponując, po raz pierwszy z wielu, swoją znajomość tego języka. Dedykacja Do najdostojniejszej, najroztropniejszej i najuczciwszej Rady... jest jednak w swojej zasadniczej części miniaturowym traktatem dydaktycznym, w którym poeta przedstawia, jak jego zdaniem powinna wyglądać przynosząca pożytek podróż do zagranicznych uczelni. Rozpoczyna od zidentyfikowania i potępienia tych peregrynantów, którzy marnują czas na błahych rozrywkach, próżnują lub żyją rozpustnie, zamiast czerpać z pobytu w odległych krajach korzyści intelektualne. Poeta staje się tutaj obrońcą postawy obywatelskiej - widzi w edukacji drogę do służenia ojczyźnie. Wzbogaca jednocześnie swój postulat odwołaniem do tradycji starożytnej, wskazuje wielkie osobistości antyku jako wzory osobowe, do których powinna przybliżać podróż edukacyjna. Rybiński tę listę bohaterów pozytywnych rozszerzy jeszcze, ukazując godny naśladowania model studiów zagranicznych, skoncentrowanych na trudnej drodze do cnoty oraz wiedzy służącej w przyszłości ojczyźnie. Wybierają go więc ci, którzy: 
[...] mając w nienawiści gnuśną bezczynność, lenistwo, przyjemności, rozkosze i inne próżne powaby tego świata, mają zwyczaj zmierzać prostą drogą w niezmordowanym trudzie, długimi i stromymi szlakami - „przez skały, przez ogień” - jedynie ku cnocie i nieśmiertelnej wiedzy; którzy, osiągnąwszy należyty cel podróży, zyskali sobie samym nieśmiertelną pamięć swego imienia, ojczyźnie natomiast znakomity zaszczyt i pożytek (Rybiński, 2015, s. 71)3.

Aby wskazać przykłady owego postępowania, poeta sięga do mitologii i historii antycznej, wskazując jako modelowych podróżników kolejno: Odyseusza, Homera, Likurga, Solona, Anacharsisa, Pitagorasa, Herodota i Diodora Sycylijczyka.

W krótkim traktacie edukacyjnym ${ }^{4}$, zamieszczonym przed samym cyklem elegijnym, Rybiński ukazuje siebie jako bezinteresownie skupioną jedynie na osiąganiu cnoty oraz wiedzy osobę, która dzięki temu może służyć ojczyźnie, propaguje zatem obywatelski model humanizmu (Garin, 1969, s. 31-35, 56-61; Kristeller, 1985, s. 102-103; Ullmann, 1985, s. 134-167). Wyraża jednocześnie swoje poglądy na edukację, popierając te idee zarówno własnym doświadczeniem, jak i powołując się na tradycję antyczną.

Funkcję pragmatyczną pełnią w cyklu przywołania niektórych ze wskazywanych przez Rybińskiego znajomości, jakie zdobył podczas swojej podróży po Europie. Najczęściej przywoływanym uczonym jest Jan Sturm, o którym wzmianki znajdujemy w: elegii I (w. 143-149), elegii III (w. 9-10), elegii IV (w. 31-36), elegii X (w. 13-24), gdzie Rybiński określa go następująco: „drugi Cyceron”, „król wymowy”, „świątobliwy starzec” oraz „Nestor”. Wyraźna gloryfikacja niemieckiego erudyty oraz odwołania do znajomości z nim mają związek z tym, iż reforma toruńskiego gimnazjum została przeprowadzona zgodnie z postulatami, ideami właśnie tego pedagoga (Buszewicz, Ryczek, 2015, s. 16)5. Rybiński zatem, osoba znana Sturmowi i zarazem jego apologeta, pragnął zdobyć prestiż w środowisku miejskiej elity intelektualnej i wykreować swój wizerunek jako uczonego rangi europejskiej.

Autoprezentacji poety służy również dołączony przez drukarza do zbioru utwór gratulacyjny pióra Ulryka Schobera - konrektora Gimnazjum Akademickiego w Toruniu, pedagoga, który przyczynił się do zreformowania tej placówki w duchu idei Sturma. Wprowadzenie tego tekstu w obręb dedykowanego Radzie tomu jest formą rekomendacji z wewnątrz miejskiego środowiska intelektualnego, służy budowaniu pozytywnego wizerunku nowo zatrudnionego lektora języka polskiego.

3 Wszystkie cytaty w niniejszym artykule pochodzą z najnowszego wydania elegii Rybińskiego w przekładzie Elwiry Buszewicz, w dalszej części w nawiasach podano numer elegii (cyfry rzymskie) oraz numery wersów (cyfry arabskie).

4 Rybiński w podobny sposób podkreślał wartość zagranicznych wycieczek w celach edukacyjnych w mowie wygłoszonej z okazji objęcia katedry języka polskiego w Gdańsku. Wypowiadając się o wysokim stopniu wykształcenia w mieście, mówił: „Świadczy o tym przede wszystkim to kwitnące gimnazjum [...] świadczy o tym gorąca troska i ten rozumny sposób zaprawiania w naukach potomstwa, kiedy rodzice prowadzą dzieci w pierwszym kwiecie wieku nie na rynek, nie do statków, nie na targi, nie do zajęć, ale oddają je wiernym nauczycielom [...] albo wielkie łożąc koszty odsyłają je w najbardziej odległe strony, by potem z bogatą praktyką, naukami, wielostronnym doświadczeniem, z chwałą wracały do domu, do miejsc pobytu swoich ojców, dla objęcia stanowisk" (Rybiński, 2005, s. 193-194).

5 W latach 1586-1588 wybrane traktaty pedagogiczne Sturma zostały opublikowane w toruńskim czasopiśmie „Institutio Literata". 
Innym uczonym, o którym wzmianki często pojawiają się w poszczególnych utworach Rybińskiego, jest teolog kalwiński Johann Jakob Grynaeus ${ }^{6}$, któremu polski poeta dedykował dwie pierwsze elegie cyklu. Wyraźnie widać, że mimo stałego tonu humanistycznej przyjaźni, z jaką Rybiński odnosi się do każdego ze swoich adresatów, to relacja właśnie z niemieckim teologiem zaburza nieco ten utopijny schemat równości między intelektualistami (Buszewicz, Ryczek, 2015, s. 48-49). Szczególnie wyraźne jest to w elegii I, w której poeta z nutą goryczy domaga się od Grynaeusa dedykacji:

Chociaż los mi nie dawał wciąż przebywać z tobą,

Należałem do takich, którzy cię uczcili -

Potwierdza to pieśń moja w elegijnych wierszach,

Zdobiąca twoje dzieło, o czcigodny mężu.

Daj dowód mym rodakom, że masz we mnie ucznia,

I w swojej dedykacji umieść imię moje,

A wdzięczny ci za dar ten, $\mathrm{z}$ radością stąd ruszę

$\mathrm{W}$ inne kraje, jeżeli Chrystus mi pozwoli.

(Elegia I, w. 203-210)

Jakkolwiek fragment ten jest odstępstwem od panującego w cyklu tonu serdecznej przyjaźni między ludźmi nauki lub poetami, to pokazuje w pewien sposób cechę Rybińskiego, jaką jest przypisywanie kluczowego znaczenia swojemu wizerunkowi uczonego, który na pewno zyskałby prestiż, gdyby europejskiej klasy teolog poświęcił mu swoją rozprawę (Krzywy, 2012, s. 272). Rybiński nie eksponuje jednak swoich znajomości tylko na zasadzie utylitarnej. Przyjaźń zajmuje w całym cyklu miejsce szczególne, wyraźnie podkreślane przez poetę, który miał świadomość, że relacje pomiędzy humanistami - zarówno na płaszczyźnie duchowej, jak i intelektualnej - stanowiły światopoglądowy fundament respublica litterarum (Borowski, 1992, s. 74-79; Kristeller, 1985, s. 142; Milewska-Waźbińska, 2009, s. 63-64). Charakterystyczna jest elegia XII, w której ukazany jest epizod całonocnej, serdecznej, lecz także uczonej rozmowy autora z pastorem Mikołajem Glicznerem (w. 10-22). Na podstawie utworów całego cyklu można utworzyć długą listę uczonych lub literatów, z którymi łączą Rybińskiego przyjacielskie relacje7. Utrwalając je w łacińskich elegiach, poeta, zgodnie ze starożytną praktyką, buduje swój wizerunek członka humanistycznej wspólnoty (Buszewicz, Ryczek, 2015, s. 66-67).

Rybiński nie zamykał się wyłącznie w kręgu intelektualistów. Będąc humanistą, chciał zaprezentować się również jako człowiek obyty w świecie dyplomacji oraz administracji, jako osoba, która dzięki swoim podróżom zdobyła wiedzę w dziedzinie funkcjonowania państw, miast i misji poselskich. Ten postulat w dużej mierze spełnia powołanie się poety w elegii I na znajomość z wybitnymi osobistościami dworskimi, z którymi zapoznał się w Heidelbergu (w. 119-142). Jej obszerny fragment poświęcony jest eksponowaniu znajomości z takimi osobami, jak: książę Jan Kazimierz Wittelsbach, Fabian von Dohna (doradca władcy Palatynatu), Filip III Wamboldt

\footnotetext{
6 Na temat związków Polaków z Johannem Jakobem Grynaeusem zob. Włodarski, 2001, s. 104-125.

7 Pełne omówienie tematu przyjaźni w elegiach Rybińskiego znajduje się w najnowszej edycji Ksieggi elegii podróżnych, zob. Buszewicz, Ryczek, 2015, s. 45-57.
} 
(ochmistrz i sekretarz księcia) oraz Hartmann Hartmani (palatyn na dworze Wittelsbachów). Służy zatem podkreśleniu obycia w świecie polityki oraz administracji, jakie posiada polski poeta. Ma to szczególną wartość pragmatyczną, biorąc pod uwagę, że cały cykl dedykowany jest zarządowi Torunia, gdzie Rybiński mógł liczyć na pracę nie tylko związaną z nauczaniem, lecz także jako urzędnik bądź dyplomata.

Dodatkowo Rybiński w elegii I, przy okazji opisu Sądu Komornego w Spirze, wprowadza pochwałę praw oraz ich uniwersalnego charakteru, stojącego ponad zależnościami społecznymi (w. 57-64). W ten sposób autor daje do zrozumienia, że nie musi się ograniczać do podejmowania tylko zajęć edukacyjnych, gdyż swobodnie porusza się także w świecie prawa i polityki. Działa jednocześnie na kilku płaszczyznach, eksponując swoją wszechstronność. Dlatego też w elegii XI pokazuje się jako dobry nauczyciel oraz osoba godna najwyższego zaufania.

Aby zrozumieć strategię autoprezentacji w elegiach Rybińskiego, potrzebna jest znajomość kontekstu społecznego i obyczajowego, dotyczącego peregrynacji akademickich. Jedną z kluczowych decyzji ojca posyłającego swoich synów na kilka lat za granicę było wybranie odpowiedniego preceptora. Musiał to być człowiek odpowiedzialny, o nieskazitelnej postawie moralnejmiał on spędzić z młodzieńcami następnych kilka lat, a jego zadaniem było nie tylko kierowanie ich nauką, lecz także przejęcie wszystkich praw i obowiązków ojca (Żołądź-Strzelczyk, 2012, s. 333-337). Z tego powodu Rybiński przypomina, że opiekował się synami Wacława Ostroroga:

Już za wami początek dobry słusznej drogi,

Teraz czas na to, aby kroczyć nią wytrwale.

Już od nauczycieli dobrych, pośród których

I ja się też znalazłem, zyskaliście wiele

W nauce, obyczajach i pismach łacińskich.

(Elegia XI, w. 37-41)

Poeta de facto wprowadził do swojego cyklu pochwałę od wielkopolskiego magnata, który obdarzył go tak wielkim zaufaniem, że wyznaczył na opiekuna swoich synów ${ }^{8}$. Wchodząc w rolę pedagoga, Rybiński daje swoim uczniom przestrogę przed lenistwem lub zanikiem naukowego zapału, zachęca też do dorównania w chwale wybitnemu ojcu i wróży im wspaniałą przyszłość (w. 53-66). Autor w pożegnaniu ze swoimi byłymi wychowankami przekazuje im wskazówki dotyczące dalszego rozwoju. Ujawnia się zatem jako troskliwy nauczyciel, starający się wspierać rozwój swoich podopiecznych, nawet kiedy nie jest bezpośrednio z nimi związany (Buszewicz, Ryczek, 2015, s. 44).

Autoprezentacja Rybińskiego nie ogranicza się do warstwy pragmatycznej (umiejętności pedagogiczne, znajomość osób i spraw), lecz obejmuje również projektowanie obrazu zdolnego poety, dobrze zaznajomionego ze swoim rzemiosłem. Owo drugie, artystyczne oblicze tworzone jest też na kilku płaszczyznach.

Podczas lektury elegii natychmiast rzuca się w oczy ich mitologiczna ornamentyka. Oczywiste jest, że osoba pretendująca do europejskiej wspólnoty ludzi pióra powinna sprawnie

8 Na temat nauczania Ostrorogów przez Rybińskiego zob. Buszewicz, Ryczek, 2015, s. 9. 
posługiwać się tym uniwersalnym kodem kulturowym. W większości przypadków wątki lub wtrącenia mitologiczne nie są jednak u Rybińskiego semantycznie bogate, służą raczej ostentacyjnej manifestacji znajomości śródziemnomorskiej tradycji. Często wykorzystywane są do pozytywnego wartościowania pewnych elementów rzeczywistości. Charakterystyczne dla Rybińskiego jest ukazywanie jakiejś przestrzeni jako siedziby Muz (elegia I, w. 9-10; elegia II, w. 1-8; elegia IV, w. 9-12; elegia V, w. 5) bądź zastosowanie nawiązań mitologicznych w funkcji panegirycznej (np. określenie Sturma mianem Nestora w elegii IV). Z owego banalnego schematu wyłamuje się jednak zwłaszcza elegia VI, gdzie zawarty jest piękny, poetycki opis heidelberskiego ogrodu książęcego ${ }^{9}$. Rybiński dokonuje pełnej mitologizacji jego przestrzeni. Już na samym początku Hortus Heidelbergensis przedstawiony zostaje jako domena poetyckiego natchnienia, a zatem wyrywa się z paradygmatu realistycznego, przechodząc w świat wyobrażeń mitologicznych:

Tu zazwyczaj pieśniami łagodziłem wichry

Nad płynącą z poszumem wodą rzeki Neckar,

Czy dzień nowy od wschodu wiódł porywcze konie,

Czy, gdy słabły, otulał je zmierzchu obłokiem.

(Elegia VI, w. 1-4)

Poeta, niczym mityczny Orfeusz, swym śpiewem łagodzi siłę natury, bieg koni Heliosa jest mu obojętny. Twórczość neguje lub zawiesza wręcz prawa natury, Hortus Palatinus staje się u Rybińskiego domeną wyłącznej władzy artysty. Jest to wyjątkowo oryginalna gloryfikacja roli twórcy. Żal z powodu utraty przepięknego, obfitującego we wspierającą natchnienie naturę miejsca (spowodowany wyjazdem poety, w. 7-14) łagodzi przekonanie, że istotny jest też inny rodzaj inspiracji, czerpany z piękna stworzonego ręką człowieka. I jeżeli przyroda jest mu nieprzychylna, to właśnie w sztuce innych autor odnajduje impuls do własnej ekspresji artystycznej:

A jeśli chmurne niebo groziło ulewą,

Blisko jest dom, chroniący plecy przed zmoknięciem.

Tam siedząc, oglądałem przecudne obrazy,

Ryte dłonią biegłego w sztuce rzemieślnika.

(Elegia VI, w. 23-26)

Rybiński przedstawia wizję przestrzeni idealnie wspierającej rzemiosło poetyckie. Czerpie zarówno z natury, jak i piękna wytworzonego przez artystów. W tym utworze twórca Księgi elegii podróżnych przedstawia się jako poeta o lekkim piórze, zdolny do refleksji metapoetyckich (geneza natchnienia, siła poezji, która zdolna jest kształtować świat na własny, wyjątkowy sposób). Ukazany poprzez serię sensualnych wrażeń książęcy ogród urasta do rangi locus amoenus, którego piękno opanowuje umysł (Buszewicz, Ryczek, 2015, s. 36-38).

\footnotetext{
9 Na temat historii i konstrukcji heidelberskiego ogrodu zob. Mrowcewicz, 2011, s. 110-122.
} 
Interesującym sposobem adaptacji wątków mitologicznych w obrębie cyklu elegii jest posłużenie się przez poetę motywem podróży Odyseusza jako klamrą kompozycyjno-tematyczną, wykorzystaną do opisu własnej peregrinatio academica. A zatem po obraniu w przedmowie tego herosa za jednego z wzorowych podróżników, autor już w pierwszym utworze przyrównuje subtelnie swój los do losu króla Itaki, ukazując trudną przeprawę przez Ren, podczas której gwałtowne fale biły statkiem o skały:

Nie sądziłbym, że takim umiesz wzbierać gniewem,

Kiedy się, dumny Renie, na żeglarzy srożysz,

Gdybyś mnie i mych druhów nie wiózł do pradawnych

Domostw Wangionów, które leżą w twym zakolu.

Nieposkromione fale tak nami rzucały,

Że łódź była już bliska strasznej katastrofy:

Raz to, miotana falą, trzeszczała przy skałach,

To znów się wydawało, że zanurza rufę.

Ach, ileż wraz z innymi wylewałem modłów,

Ilem ślubów gniewnemu składał Neptunowi,

Pókim z całą załogą nie dotarł do miasta

Wangionów, chlubiącego się szlachetnym winem.

(Elegia I, w. 75-86)

Pierwszy w cyklu Rybińskiego opis podróży (nawiązujący do homeryckiego eposu) przerwany zostaje przez gniew Posejdona, a życie poety zagrożone jest przez wzburzone wody, tym samym zaś osiągnięcie celu wyprawy staje się niepewne. Napięcie jednak szybko zostaje rozładowane, Rybiński nie chce w pełni utożsamiać się z herosem, który błądzi, gdyż poeta ma wyraźnie nakreślony cel poznawczy:

Podniesiony na duchu zwiedziłem, co chciałem,

Wieczorem przepłukałem winem suche gardło.

Także tu było wiele rzeczy moim oczom

Miłych, w tym mieście starym, potężnym i sławnym -

I wszystko bym wymienił, gdyby mi nie wzbraniał

Apollo, każąc dalej tkać wiersz rozpoczęty.

(Elegia I, w. 87-92)

Wątek Odysa zostaje dopełniony wraz z końcem opisów podróży Rybińskiego. W elegii XII jest to widoczne, kiedy poeta, wracając do ojczyzny z powodu zagrożenia dżumą, musi - niczym heros na Itace - ukrywać swoją tożsamość:

Przybywam więc do Gniezna, gdzie niegdyś, jak mówią, Lech, wycinając drzewa, pierwsze stawił domy.

Słowom nikt tu nie wierzy, ledwie pozwolono

Przejść przez bramę, choć glejty mieliśmy na drogę. 
Dla jednych więc chirurgiem, dla innych poznańskim

Byłem kupcem lub Szkotem $\mathrm{z}$ towarem na grzbiecie.

(Elegia XII, w. 41-46)

Scalając w ten sposób relację ze swojej podróży, Rybiński pokazuje, z jaką swobodą i subtelnością posługuje się dziedzictwem gloryfikowanej kultury antycznej.

Autor zbioru wykazał się ponadto dużą inwencją w kwestii genologicznej i retorycznej. Pomimo iż w tytule widnieje nazwa hodoeporikon (Krzywy, 2001, s. 49-119; 2013), to jednak część elegii należy do innych typów liryki zaczerpniętych ze starożytności, takich jak np. propemptikon, prozopopeja, dialog poetycki. Występują też partie narracyjne oraz laudacyjne (Buszewicz, Ryczek, 2015, s. 28-29). Na taką różnorodność pozwalało rozmycie wyznaczników gatunkowych elegii w poetyce doby odrodzenia, zarówno w teorii Franciszka Robortella, jak i Juliusza Cezara Scaligera (Urban-Godziek, 2005, s. 89-93). Gatunek ten umożliwiał dużą swobodę w doborze tematyki oraz sposobie realizacji, co niewątpliwie było atrakcyjne dla ambitnego poety.

Księga elegii podróżnych Jana Rybińskiego to swoista wizytówka renesansowego humanisty. Autor w oryginalny i często niebezpośredni sposób przedstawia swoją osobę ważnym osobistościom miasta, do którego przyjechał, przyjmując nową posadę. Wyraźne jest w utworach nastawienie na autoprezentację na poziomie pragmatycznym, gdy poeta odwołuje się do wątków autobiograficznych jako medium przekazu informacji o nabytych przez siebie umiejętnościach z zakresu dyplomacji, pedagogiki, administracji oraz prawa, a także o wysokim poziomie swojego humanistycznego wykształcenia. Wprowadza też do zbioru, przy pomocy utworu gratulacyjnego pióra Ulryka Schobera, swego rodzaju rekomendację pochodzącą z wewnątrz samego toruńskiego grona intelektualnego. Natomiast poprzez odwołanie się do czasu spędzonego jako preceptor Ostrorogów, buduje etos mentora. Dzięki tym zabiegom może wejść w nowe środowisko z ustalonym już wizerunkiem człowieka uczonego i obytego w świecie. Nastawienie czysto utylitarne nie jest jednak wyłączną dominantą kompozycyjno-tematyczną cyklu, istotny jest również aspekt artystyczny. Rybiński, oczekując spotkania z toruńskimi intelektualistami, wyraził w elegiach swoją przynależność do modelu kultury zawartego w pojęciu respublica litteraria. Zręcznie posługuje się językami starożytnymi oraz mitologią, czyli głównymi ogólnoeuropejskimi kodami kulturowymi doby renesansu. Nie ogranicza się jednak do manifestacji jedynie swojej erudycji, lecz pokazuje także swą zdolność do tworzenia subtelnej poezji, bogatej w refleksję metapoetycką. Z cyklu elegii emanują zarówno humanistyczne wartości (afirmacja przyjaźni, wiedzy, ciekawości świata), jak i umiejętności poetyckie Rybińskiego. Autor stworzył w ten sposób wizerunek uzdolnionego i niepospolitego renesansowego humanisty. 


\section{Bibliografia podmiotowa}

Rybiński, J. (2005). Mowa o ważności i o pożytku języków w ogóle, a języka polskiego w szczególności. W: Mowy staropolskie. Wybór i oprac. B. Nadolski. Wrocław: Zakład Narodowy im. Ossolińskich. Rybiński, J. (2015). Księga elegii podróżnych. Przekł. E. Buszewicz. Oprac. i wstęp E. Buszewicz, W. Ryczek. Warszawa: Wydawnictwo Naukowe Sub Lupa.

\section{Bibliografia przedmiotowa}

Bielak, J. (2000). Rola Gimnazjum Akademickiego w Gdańsku w kształtowaniu kultury i sztuki opartej o tradycję antyczną. W: T. Grzybkowska (red.), Mit Odysa w Gdańsku (s. 93-101). Gdańsk: Wydawnictwo Uniwersytetu Gdańskiego.

Bieńkowski, T. (1976). Antyk w literaturze i kulturze staropolskiej (1450-1750). Wrocław: Zakład Narodowy im. Ossolińskich.

Borowski, A. (1992). Renesans. Warszawa: Wydawnictwa Szkolne i Pedagogiczne.

Buszewicz, E., Ryczek, W. (2015). Wstęp. W: J. Rybiński. Księga elegii podróżnych (s. 5-58). Przekł. E. Buszewicz. Oprac. i wstęp E. Buszewicz, W. Ryczek. Warszawa: Wydawnictwo Naukowe Sub Lupa.

Curtius, E.R. (1997). Literatura europejska i łacińskie średniowiecze. Oprac. i przekł. A. Borowski. Kraków: TAiWPN Universitas.

Garin, E. (1969). Filozofia Odrodzenia we Włoszech. Przeł. K. Żaboklicki. Warszawa: Państwowe Wydawnictwo Naukowe.

Grzybkowska, T. (2000). Mit i antykizacja w sztuce gdańskiej. W: T. Grzybkowska (red.), Mit Odysa w Gdańsku (s. 39-49). Gdańsk: Wydawnictwo Uniwersytetu Gdańskiego.

Kotarski, E. (1993). Gdańska poezja okolicznościowa XVII wieku. Gdańsk: Instytut Bałtycki.

Kristeller, P.O. (1985). Myśl moralna humanizmu renesansowego. W: P. Kristeller, Humanizm i filozofia. Cztery studia (s. 37-88). Przekł. M. Szymański. Warszawa: Polska Akademia Nauk Instytut Filozofii i Socjologii.

Krzywy, R. (2001). Od hodoeporikonu do eposu peregrynackiego. Studium z historii form literackich. Warszawa: Wydział Polonistyczny Uniwersytetu Warszawskiego.

Krzywy, R. (2012). Peregrynacja edukacyjna jako topos pochwalny w polskiej biografistyce renesansowej. Przyczynek do antropologii podróżowania. W: M. Saczyńska, E. Wółkiewicz (red.), Samotrzeć, w kompanii czy z orszakiem? Społeczne aspekty podróżowania w średniowieczu i w czasach nowożytnych (s. 261-282). Warszawa: Wydawnictwo Instytutu Archeologii i Etnologii Polskiej Akademii Nauk.

Krzywy, R. (2013). Wędrówki z Mnemozyne. Studia o topice dawnego podróżopisarstwa. Warszawa: Muzeum Pałac w Wilanowie.

Milewska-Waźbińska, B. (2009). Przyjaźń humanistów - wzorce, postawy, ekspresja literacka. W: A. Nowicka-Jeżowa, M. Cieński (red.), Humanizm polski. Długie trwanie - tradycje - wspótczesność (s. 63-74). Warszawa: Wydawnictwo Neriton.

Mrowcewicz, K. (2011). Małe folio (historia jednego wiersza). Warszawa: Instytut Badań Literackich PAN.

Nadolski, B. (1961). Jana Rybińskiego „Hodoeporicorum liber”. W: Z. Czerny (red.), Księga pamiątkowa ku czci Stanisława Pigonia. Kraków: Państwowe Wydawnictwo Naukowe. 
Nadolski, B. (1976). Wstęp. W: Poezja renesansowa na Pomorzu (s. 7-59). Wybór i wstęp B. Nadolski. Gdańsk: Wydawnictwo Morskie Gdańsk.

Nowak, Z. (1997). Zapomniany poeta pomorski - Jan Rybiński. W: S. Grzeszczuk (red.), Pisarze staropolscy. Sylwetki (s. 368-390). T. 2. Warszawa: Wiedza Powszechna.

Nowak, Z., Świderska A. (1961). Jan Rybiński: zapomniany poeta pomorski doby Odrodzenia. Pamiętnik Literacki, 52 (4), 321-371.

Ryczek, W. (2015). Cieniom poety teologa. O nieznanym łacińskim epicedium Jana Rybińskiego. Ruch Literacki, 66 (2), 127-141.

Salmonowicz, S. (2005). W staropolskim Toruniu (XVI-XVIII w.). Studia i szkice. Toruń: Towarzystwo Organizacji i Kierownictwa „Dom Organizatora”.

Ullmann, W. (1985). Średniowieczne korzenie renesansowego humanizmu. Przekł. J. Mach. Łódź: Wydawnictwo Łódzkie.

Urban-Godziek, G. (2005). Elegia renesansowa. Przemiany gatunku $w$ Polsce $i w$ Europie. Kraków: TAiWPN Universitas.

Włodarski, M. (2001). Dwa wieki kulturalnych i literackich powiązań polsko-bazylejskich 1433-1632. Kraków: TAiWPN Universitas.

Żołądź-Strzelczyk, D. (2012). „Nadobna to jest rzecz młodemu człowiekowi do cudzych krajów się przejeździć” - miejsce podróży w edukacji polskiej szlachty XVI-XVII wieku. W: M. Saczyńska, E. Wółkiewicz (red.), Samotrzeć, w kompanii czy z orszakiem? Społeczne aspekty podróżowania $w$ średniowieczu i w czasach nowożytnych (s. 323-338). Warszawa: Wydawnictwo Instytutu Archeologii i Etnologii Polskiej Akademii Nauk.

\section{Strategies for creating the image of a humanist in the "Hodoeporicorum liber unus" (“The Book of Traveling Elegies") by Jan Rybiński}

\section{Summary}

“The Book of Traveling Elegies” by Jan Rybiński is not just a description of the author's journey especially to foreign universities, in order to gain extensive humanistic knowledge, but, and this is probably the most interesting, is also a kind of „visiting card” for the Renaissance intellectual member of the respublica litterarum community. The article presents the methods that Rybiński used to present his person in a subtle and clear way to a new, but also demanding environment of intellectuals gathered in Torun. The article presents both the pragmatic aspect of this self-presentation, related to the work undertaken by the poet, as well as the purely artistic one, addressed directly to local Toruń humanists.

Słowa kluczowe: humanizm, Jan Rybiński, elegia, autowizerunek, mitologia

Keywords: humanism, Jan Rybiński, elegy, self-image, mythology 